\title{
Predicting Job Expectations of Millennials: A Generation with Soaring Work Projections
}

\author{
C-RIM Poonam Arora \\ Assistant Professor, St. Kabir Institute of Professional Studies \\ Ahmedabad - 380054 \\ Email - poonam.a@skips.in
}

\begin{abstract}
In today's competitive world, organisations are struggling with shortage of people rather than dearth availability of talent for running businesses. With previous two generations already retired or at the senior positions, employing Millennials is the only option that managers have. Managers are now finding it difficult to fill the vacant positions as either the employers are demanding those skills and abilities which are hypothetical in today's world or expectations of this generation from their managers is far from reality and are soaringly huge. Employing Millennials is one of the mammoth challenges that managers are facing in twenty first century. This generation is studied and observed to be lot different from other generations as far as their work spirits and expectations are concerned. Millennials have unique needs and unparalleled demands from their future employer that must be addressed to promote retention and highlight development and management.

It is therefore crucial to understand and analyze the mindsets and work attitudes of Millennial freshers with which they plan to join the workplace. It is extremely important to study and analyze the factors affecting the job preferences of Millennial being curried and prepared by them. Hence this research proposes to study the factors affecting job expectations of Millennials pertaining to management field with special reference to Ahmedabad city.

The present study aims to find out the importance of preferred factors affecting job projections of Millennials. The paper endeavors to unveil the impact of these factors on overall job expectations of Millennials.
\end{abstract}

Keywords: Millennials, Generation Y, Job Expectations, Salary, Freedom at Workplace, Job Profile, Training Opportunities. 


\section{Introduction}

Strauss and Howe, the generation gurus, say that "History creates generations, and generations create history. Among previous three generations studied after World War II, Millennials are observed to have striking values and expectations which are found to be different and difficult to tackle (Strauss \& Howe, 2009). This generation is observed to be habituated with job hopping and so portrays high attrition rate. They leave an organisation within short durations of time. So the recent cohorts of Millennials who are new recruits form an onerously critical community. In future years Millennials will form the largest chunk of the majority of corporate workforce. Millennials have different thoughts and views about work, team mates and relationships with their colleagues impacted due to the changes in surroundings and the environment they grew up in.

Millennials do not want to adapt in an organisation rather they want the organisation to adapt according to their needs. They are very choosy about the kind the employer they want to work in future. For them, work does not come first as they work to live and not live to work. Millennials want an environment where they have freedom to work. This generation hate micro management and hence want the flexibility to plan their own work and decide how they want to take it ahead. They want the freedom to express their views and participate in meetings. They demand their right to take their own decisions and work without restrictions. Generation $\mathrm{Y}$ prefers to work with superiors who are approachable and support them in their career development by providing them with training opportunities. With organisational development; Millennials are also conscious about their personal development and would prefer to work for companies sponsoring development programs for them. Millennials want to participate in crucial decision making meetings regardless to the level of hierarchy they fall in. They want to share their opinions regarding organisational strategic decisions. Generation Y prefer to work on those profiles which are challenging and not monotonous. The generation is attracted to those organizations which provide right salary for the kind of work which is assigned to them added with extra incentives. Generation Y want to work for companies who are adopting new systems of technology and implementing them into work processes.

Generation $\mathrm{Y}$ has unique characteristics that affect learning as they want to learn even in their own ways. Generation $\mathrm{Y}$ that too in the management field are considered to be very focused about their studies as well as their future. They have a deep sense of understanding and have some predetermined idea of their workspace and have too many specific expectations in terms of profile, salary and incentives, career development and freedom expected from it. To ensure success, employers need to understand that Millennials cannot be forced into the mold of past generations and therefore it is critically crucial that Indian Millennials are studied afresh with a new angle so that future employer benefits from it and can strategize to retain them well. 


\section{Literature Review}

Generation Y involves individuals born between 1980's and 2000s. These individuals have been named differently by different researchers like Generation Y, Gen Yers, Millennial Generation, Echo Boomers or only Millennial (Baltes, 1980). The terms Generation Y and Millennials are

generally used interchangeably and after previous two generations, this generation is being now recognized as different (Zevenbergen, 2004).

Millennial are believed to be very choosy about the HR policies and terms offered by some employer before accepting a job offer which proves their different attitude and highly soaring expectations (Arora \& Kshatriya, 2017). They are assertive above greater accommodation to their needs as they are confident about their self-worth and hence demanding of higher grades and (Black, 2010). Millennials are born leaders who write their own rules with sprinkled hard work, innovation, creativity and confidence (Arora \& Kshatriya, 2018).Generation Y do not bother much on how and when the work will get done, it's just that it gets done (Alch, 2000). Millennials rated challenging job profile as one of the top parameter, they evaluate before accepting an employment offer (Khera \& Malik, 2017). The learning and acquiring skill of this group is very different from earlier generations as they seek out creative challenges (Saxena \& Jain, 2012;Spiro, 2006). The primal purpose of classy chunk of Millennials' work life is performing an important but meaningfulness work profile (Arora \& Kshatriya 2017). It's also concluded by numerous researchers that compensation package and opportunities for career development that the company has and follows are the components that majorly impact Millennial's acceptance of an employment offer (Aminul, Cheong, Yusuf \& Desa, 2011; Rhi, 2008). Generation Y has witnessed their parents working very hard for higher salaries and promotions and so this generation does not want to work in the same way (Arora \& Kshatriya, 2019). Initial salary and additional bonuses work importantly in choosing a job (Terjeson, Vinnicombe \& Freeman, 2007). Millennials believe that they are worthy of receiving high salaries (Treuren \& Anderson, 2010).

Millennials believe in lifelong idea of learning and so want more career growth opportunities following their exalted expectations of training and development opportunities $(\mathrm{Ng}$ et. al, 2010; Kamau et al., 2014). They are quite choosy in their choice of workplace as training and development opportunities is of high importance in their life (Solnet \& Hood, 2008) and so they will select a work environment that best meets their perceived learning needs (Maxwell \& Broadbridge, 2016). The most important factors which they consider before preferring a company are growth opportunities and career progression chances (Mamtha \& Nandini, 2013; Arora \& Kshatriya, 2019). According to Millennials, a demand which employers must meet is flexible working schedule, more time to travel and an improved work-life balance, (Broadbridge et al, 2007). Millennials want flexible work schedules and a flexi environment in jobs (Saxena\& Jain, 2012; Truren \& Anderson, 2010). Work values are expressed in terms of having balance between their personal life and work hours, having flexible work life, having independence without getting pestered and having autonomy at workplace (Queiri et al., 2014). Millennials' advanced prospects and development orientation assert them to take up a job that is well paid and meaningful (Alsop 2008). The results revealed that job profile and stability, salary, flexible 
schedule, training and feedback are the key factors that are expected out from the employers (Tremblay et al., 2010). There are a contradicting opinions about who Millennials are, what their real characteristics are, what they think and value and how they will behave on joining an employer (Arora \& Kshatriya, 2019). The research published on Millennials is confusing as well as contradictory which forces to give a good thinking to it (Deal et al., 2010)

Innumerable researches have been conducted on managing the generational diversity and understanding Millennials but research on Millennials from Indian perspective are scanty. Also, study on Millennials with respect to their stream of education is yet another area which remains unexplored. Various researches which are done till now have taken school students, graduates and working professionals as their respondents but no research has ever taken postgraduate management students who are ready to join corporate world. This research focuses on four factors extracted from literature review with management postgraduate students as its respondents.

\section{Objectives}

The study tries and understand the job expectations of Millennials based on four factors. The key objectives of this research are:

1. To understand the factors affecting job expectations of Millennials.

2. To study the gender difference over job expectations.

3. To identify the effect of freedom at workplace, job profile, training opportunities offered, and salary on job expectations of millennial management students.

\section{Research Methodology}

This research paper uses descriptive research following the quantitative approach of data collection. For collecting the opinions of the respondents, questionnaire as a data collection was prepared and the survey sampled over 180 students from management background studying their post-graduation course in Ahmedabad. The source of data collection is majorly primary following non-probability convenience sampling

The study uses four different categories of independent variables i.e. freedom at workplace, job profile, training opportunities offered and salary with one dependent variable as job expectations. The independent variable is categorical in nature while the dependent variable is continuous on scale. The study started with many research questions like whether the factors under study are capable of creating an impact in Millennials' expectations. Are these factors creating variability in overall expectations? Whether these variables are able to predict job expectations? Will the change in one factor be able to create any change in overall job expectations? Hence, the main aim of the study is to identify the impact of factors on job expectations of management Millennials and so the following hypothesis are framed:

Ho1: There is no significance difference of job expectations over gender.

Ho2: There is no significance prediction of job expectations by freedom at workplace Ho3: There is no significance prediction of job expectations by job profile 
Ho4: There is no significance prediction of job expectations by training opportunities offered

Ho5: There is no significance prediction of job expectations by salary

The data is collected from 180 postgraduate management students out of which 78 are females and 102 are males. The data was gathered from first year as well as second year students. 88 students are from second year and 92 belong to first year of their post-graduation.

\section{Analytic Procedure}

The survey was taken on Generation Y respondents and questions about the factors affecting job expectations were asked. The confidence interval test is applied to check the precision and accuracy of the obtained data relating to each factor corresponding to all the statements. The percentage of the Generation Y confidently responding was observed to be above $70 \%$ @ 95\% level of confidence and so the items of the questionnaire were found to be fit for the questionnaire. The Cronbach's alpha value in reliability test was observed to be 0.915 which indicates a high level of internal consistency for the scale with this specific sample.

Reliability Statistics

\begin{tabular}{|r|r|r|}
\hline Cronbach's Alpha & $\begin{array}{c}\text { Cronbach's Alpha } \\
\text { Based on } \\
\text { Standardized Items }\end{array}$ & N of Items \\
\hline .911 & .915 & 23 \\
\hline
\end{tabular}

\section{Table 1: Cronbach's alpha test}

The responses of students were taken on a scale of 5 asking them to rate the importance of the four factors in their expectations from a job. The data on job expectations was recorded for both males and females. ANOVA test is applied to check the significance difference in job expectations of male and female students.

ANOVA

JOB EXPECTATION
\begin{tabular}{|l|r|r|r|r|r|}
\hline & \multicolumn{1}{|c|}{$\begin{array}{l}\text { Sum of } \\
\text { Squares }\end{array}$} & \multicolumn{1}{c|}{ df } & $\begin{array}{c}\text { Mean } \\
\text { Square }\end{array}$ & F & Sig. \\
\hline $\begin{array}{l}\text { Between } \\
\text { Groups }\end{array}$ & 631.477 & 1 & 631.477 & 20.642 & .120 \\
$\begin{array}{l}\text { Within Groups } \\
\text { Total }\end{array}$ & $\begin{array}{l}5445.434 \\
6076.911\end{array}$ & 178 & 30.592 & & \\
\hline
\end{tabular}

Table 2: ANOVA Table 
Significance value in table above shows that the value is .120 which is greater than 0.05 and so null hypothesis (Ho1) is accepted which shows that there is no significance difference between the job expectations of males and females. It is not that males prefer a work variable higher or females weigh a variable lower. Males and females have similar expectations from their jobs.

Now, to understand the importance of variables impacting job expectations, the mean score value is calculated based on the responses received. The following figure exhibits that freedom to work is the highest rated factor with a mean of 4.5 by the respondents followed by a very small difference in job profile. Millennials need no instructions in doing or completing a job. They are confident and consider themselves self-sufficient to design and carry out their work plans but the crucial factor is the kind of profile they are working on. Millennials demand profiles which can challenge their abilities and insist them to bring out the best in them.

The third rated factor with a mean score of 3.5 is salary which is a crucial non deniable factor in keeping the morale high and enhancing the motivation to work. The last factor which is rated lowest with a mean of 1.0 is the availability of training opportunities being offered by employer.

Fig 1: Mean Score of Work Variables

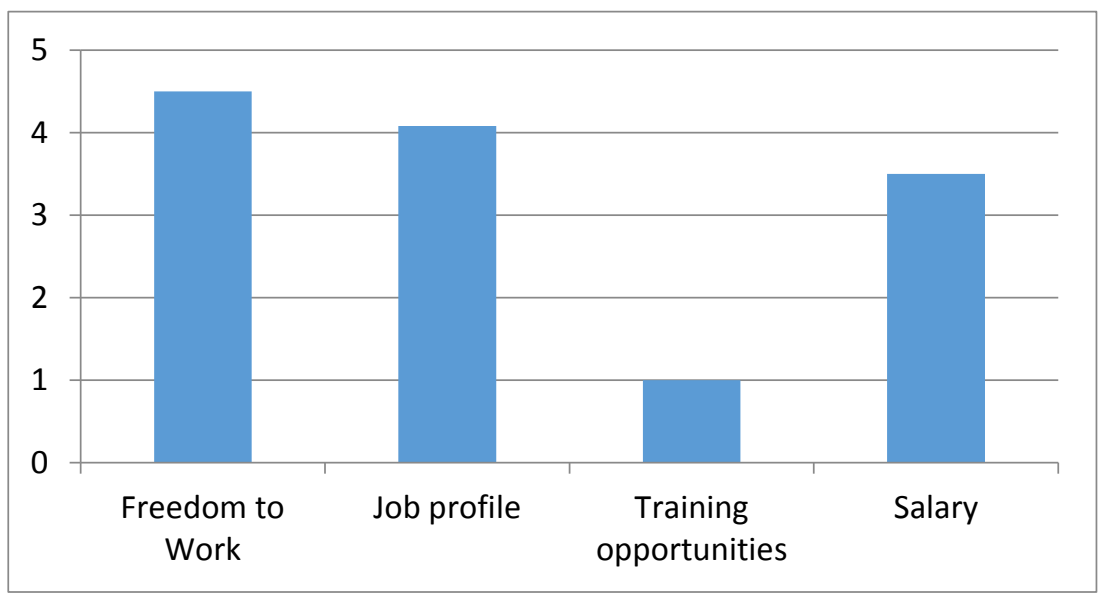

Based on the objectives of the study 4 hypotheses on prediction of job expectations were formulated and were tested with reference to the variable job expectations. The keenness here is to know whether these variables predict the dependent variable or not. Multiple regression is applied to check the prediction.

The value of $\mathrm{R}$ shown in the table below depicted the correlation of job expectation with the independent variables. The value of 0.807 proved a strong correlation between the independent variables which established a robust relationship of these variables with dependent variable job expectation. The value of $\mathrm{R}$ square which was 0.843 showed the variability caused by all the predictors in dependent variable. Here this value affirmed the impact of independent variables on dependent variable. This established the fact that $84 \%$ of variation is being created by these variables in predicting expectations from job. The sig $\mathrm{f}$ change value was 0.004 which was found 
to be less than 0.05 @ 95\% Confidence and so the regression proved to be significant. Also, Durbin Watson was 1.076, which verified that there is no auto correlation amongst the independent variables. Also, the sig value in Anova table came out as 0.004 which shows that the regression between the variables is valid and significant.

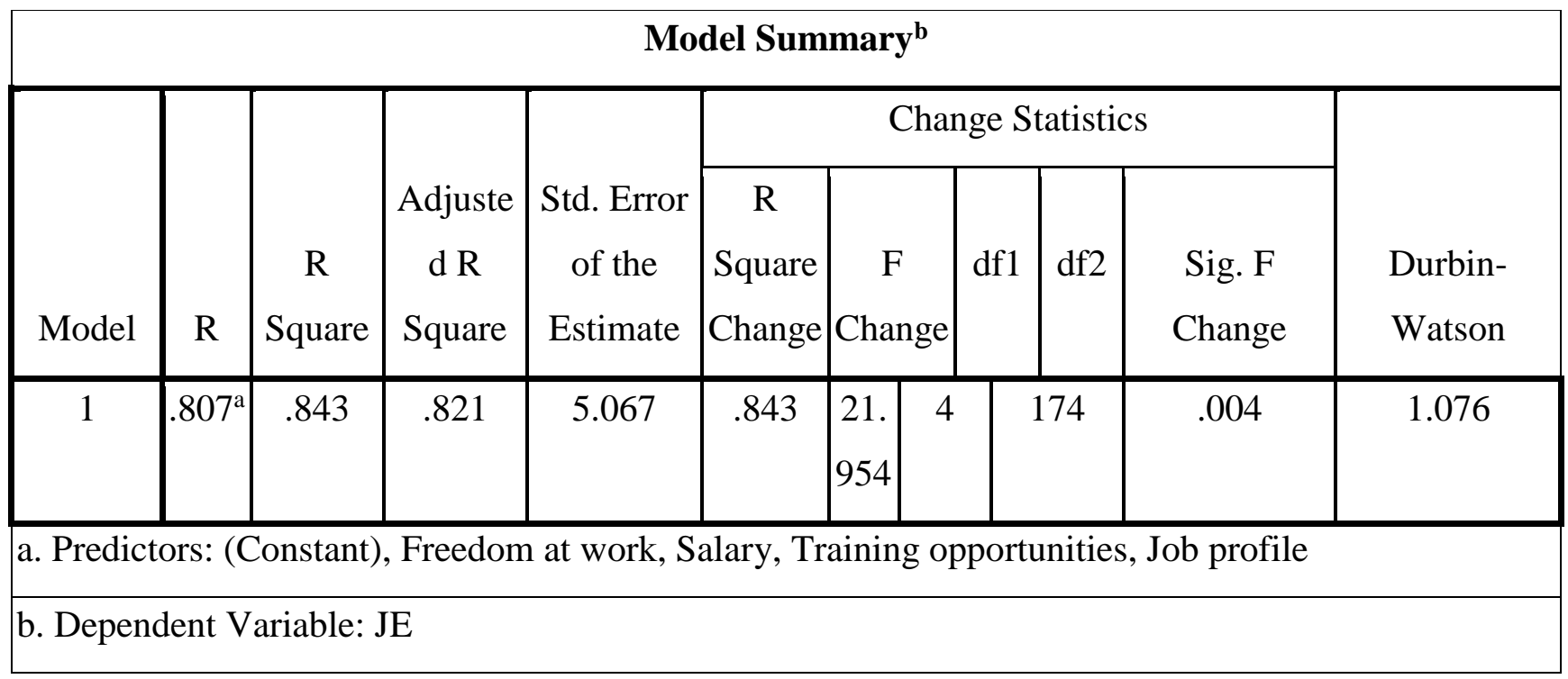

\section{Table 3: Model Summary}

The table below showed the four independent variables as used in the model. Looking at the standardized coefficient, beta showed the standard weight of each variable and the type of association it has with job expectations of respondents which helped in comparing the strength of the effect of each individual predictor variable to the dependent variable as the higher the absolute value of the beta coefficient, the stronger is the effect.

\begin{tabular}{|c|c|c|c|c|c|c|c|c|}
\hline \multicolumn{9}{|c|}{ Coefficients $^{a}$} \\
\hline \multirow{2}{*}{\multicolumn{2}{|c|}{ Model }} & \multicolumn{2}{|c|}{$\begin{array}{c}\text { Unstandardized } \\
\text { Coefficients }\end{array}$} & \multirow{2}{*}{$\begin{array}{c}\text { Standardized } \\
\text { Coefficients } \\
\text { Beta }\end{array}$} & \multirow[b]{2}{*}{$\mathrm{t}$} & \multirow[b]{2}{*}{ Sig. } & \multicolumn{2}{|c|}{ Collinearity Statistics } \\
\hline & & B & Error & & & & Tolerance & VIF \\
\hline \multirow[t]{3}{*}{1} & (Constant) & 14.603 & 3.298 & & 10.428 & .000 & & \\
\hline & $\begin{array}{l}\text { Freedom to } \\
\text { Work }\end{array}$ & $\begin{array}{l}.834 \\
874\end{array}$ & $\begin{array}{l}1.123 \\
360\end{array}$ & .542 & 6.123 & .000 & .654 & 1.645 \\
\hline & Job profile & & & & & & & \\
\hline
\end{tabular}




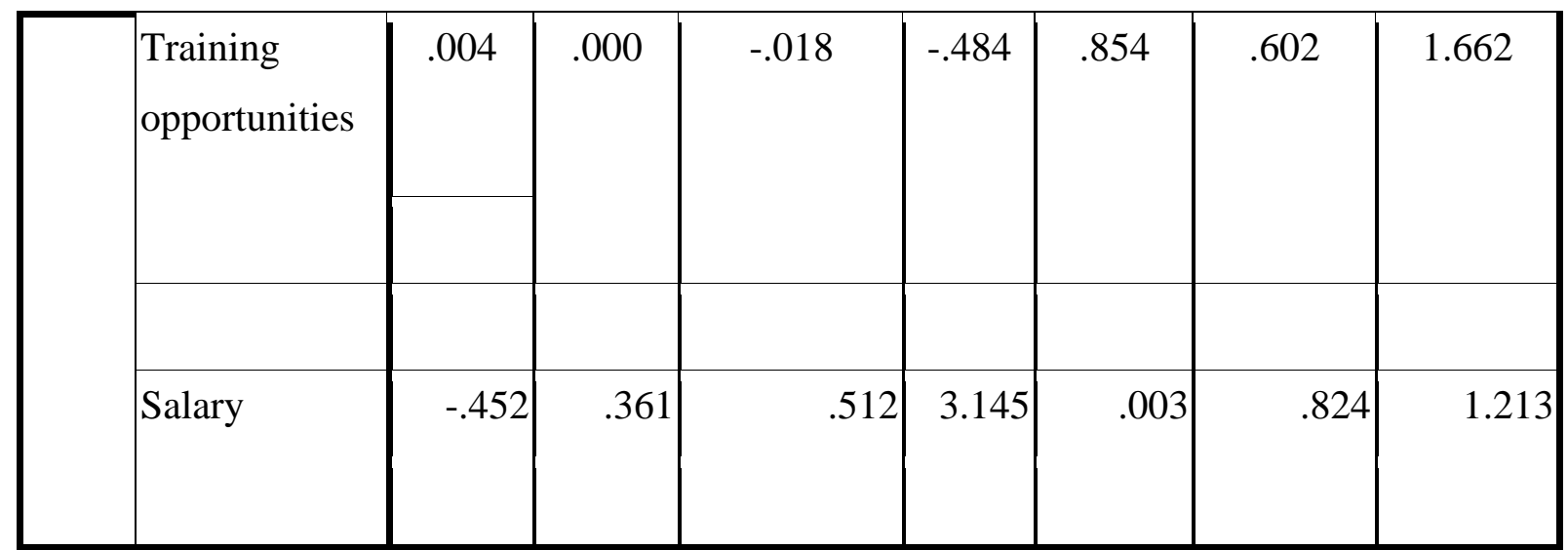

a. Dependent Variable: JE

Table 4: Regression Coefficients

Here, three variables have significant standardized regression weights (freedom at work, Beta=$.542, t=6.163, \mathrm{p}<.05$ and job profile, Beta $=.519, t=5.202, \mathrm{p}<.05$ and salary with Beta $=$ 0.361 at $\mathrm{p}<0.05$ ): which depicts that each of these three variables are significant contributor to predicting job expectations while training opportunities does not appear to add unique predictive power when the effects of the other predictors are held constant as here Beta $=-.018$ with $\mathrm{p}=$ .854) which established that three out of four variables have significant standard weights; they are positively associated and are significant contributor in predicting workplace expectations but the fourth one.

Comparing the beta values, it also proves the fact that the maximum impact is created by the variable freedom to work followed by job profile and then salary. Analyzing the co linearity statistics, neither tolerance is approaching 0 nor is VIF approaching 10 which affirmed again that there is no multicollinearity problem with the regression model created in this research

Lastly, here the sig value for freedom to work is 0.000 @ $5 \%$ LOS which according to the hypothesis testing rule is lower than 0.05 which says that alternate hypothesis is accepted and there is significant prediction of job expectations by the variable. For the next variable, the sig value for job profile is 0.040 @ 5\% which again proved that there is significant prediction of workplace expectations by profile and same is for third variable salary which has $\mathrm{p}$ value less than 0.05 which proved alternate hypothesis to be true establishing that there is significant prediction of workplace expectations by salary. Lastly, for training opportunity, as sig value is 0.854 which is greater than 0.05 proves that there is no significant prediction of workplace expectations by this variable.

\section{Conclusion}

Millennials from management field are focused and conscious about their career and future. They have a deep sense of understanding and have predetermined idea of their workspace and have high expectations about it. They have their own inbuilt expectations and want to choose an 
employer which fits in their knitted framework of expectations only. Generation $\mathrm{Y}$ has strong ideology and so they are not ready to mould themselves according to the culture and conditions of employer but want to pick a job which satisfy their set of expectations.

The study has shown striking and interesting findings about the soaring job expectations of management students which doesn't specifically differ over gender. These findings are based on the four basic pillars of this study. The study proved that the three variables freedom at workplace, job profile and salary are crucial in predicting job expectations of a Millennial while training opportunities offered doesn't significantly weigh prediction of their expectations. This generation is most concerned about the freedom on the job. For Millennials, 'Freedom' is a word which covers everything and anything they desire and need it to be available at the workplace. Be it freedom to design and plan their work and carry it out in their own way or freedom to take decisions relating to their work. They want to participate and put their views on discussion table and they want to have the exemption of raising out their voice to put up their opinions and questions thus wanting a supportive and non-interfering environment. They want freedom of using technology at their workplace so that they are always connected with the world through social media. Secondly, the study revealed the fact that Generation Y won't mind working for long hours given their work profile is interesting and meaningful with the ample role clarity provided by the supervisor. They won't mind working towards and for the deadlines given that there is no waiver in the job description on joining the organisation as was offered before. Also, the job assigned should relate to their area of specialization so that they can put in their full effort. Right salary is the third factor that they expect from their employer as they consider worthy enough to draw a handsome package including perks and benefits because of the experience and academic intellect that they have. They want interesting profiles and they are ready to stay late at workplace for doing such jobs but if they are not paid well they would not take even an interesting job. Financial gains are what they expect and this is the first job satisfaction criterion. Millennials want to be financially independent and live luxurious life so they demand to be paid right compensation. The absence of training at the workplace doesn't affect them as they feel that they are ready to handle any challenging job.

Millennial is the most unique generation that has striking features. There are different factors, different reasons, different stories and different expectations that this generation serves to their employer. The challenge is to provide the right set of value propositions like work freedom, freedom to decision making, challenging job profiles and adequate salary which can keep them committed towards the workplace. Organizations need to review their retention strategies to match expectations of their employees from their workplace.

\section{References}

1. Alch, M. L. (2000). Get ready for the Next generation. Training \& Development, 54(2), 32-34.

2. Alsop, R. (2008). The trophy kids grow up: How the millennial generation is shaking up the workplace. John Wiley \& Sons. 
3. Arora, P., \& Kshatriya, K. P. (2017). Millennials: The New Generation with High Employment Expectations. International Journal, 5(8), 101- 109.

4. Arora, P., \& Kshatriya, K. P. (2018). Redefining Millennials: Understanding characteristics and Perceptions of Generation Y, International Research Journal of Human Resources and Social Sciences, 5(03), 181-199.

5. Arora, P., \& Kshatriya, K. P. (2019). A Comprehensive Study on Analogical Factors affecting Workplace Expectations of Different Generations, International Journal of Management Studies, Researchers world,6(07),66-76. DOI: 10.18843/ijms/v6i1 (7)/08.

6. Baltes, P. B., Reese, H. W., \& Lipsitt, L. P. (1980). Life-span developmental psychology. Annual Review of Psychology, 31, 65-110.

7. Black, A. (2010). Gen Y: Who they are and how they learn. Educational Horizons, 88(2), 92-101.

8. Broadbridge, A. M, Maxwell, G. A., \& Ogden, S. M. (2007). Experiences, perceptions, and expectations of retail employment for Generation Y. Career Development International, 12(6), 523-544

9. Deal, J. J., Altman, D. G., \& Rogelberg, S. G. (2010). Millennials at work: What we know and what we need to do (if anything). Journal of Business and Psychology, 25(2), 191-199.

10. Howe, N., \& Strauss, W. (2009). Millennials rising: The next great generation. Vintage.

11. Islam, A., Cheong, T. W., Yusuf, D. H. M., \& Desa, H. (2011). A Study on'Generation Y'Behaviours at Workplace in Penang. Journal of Applied Sciences Research, 7(11), 1802-1812.

12. Kamau, J. N., Njau, M. M., \& Wanyagi, J. (2014). Factors Influencing Work Attitude among „Generation (A Case of Africa Nazarene University). European Scientific Journal, ESJ, 10(10).

13. Lavoie-Tremblay, M., Leclerc, E., Marchionni, C., \& Drevniok, U. (2010). The needs and expectations of generation $\mathrm{Y}$ nurses in the workplace. Journal for Nurses in Professional Development, 26(1), 2-8.

14. Mamtha \& Nandini (2013). Career expectations of Generation Y IT Employees with special reference to Banagalore. International Global Research analysis, Vol-2,issue 6

15. Maxwell, G. A., \& Broadbridge, A. M. (2016). Generation Ys' employment expectations: UK undergraduates' opinions on enjoyment, opportunity and progression. Studies in Higher Education, 1-17.

16. Ng, E. S., Schweitzer, L., \& Lyons, S. T. (2010). New generation, great expectations: A field study of the millennial generation. Journal of Business and Psychology, 25(2), 281292

17. Queiri, A., Yusoff, W. F. W., \& Dwaikat, N. (2014). Generation-Y Employees' Turnover: Work-Values Fit Perspective. International Journal of Business and Management, 9(11), 199. 
18. Robert half International, (2008). What millennial workers want: How to attract and retain Gen Y employees. Hotjobs.com. RHI-0308-0056

19. Saxena \& Jain,(2012). Managing Career Aspirations of Generation Y at Work Place.International Journal of Adnaced Research in Computer Science and Software Engineering.Vol 2

20. Shikha N. Khera Sahil Malik , (2017)," Conceptualizing and measuring life priorities of Generation Y: evidences from Indian context ", Industrial and Commercial Training, Vol. 49 Iss 2 pp. $80-86$

21. Solnet, D., \& Hood, A. (2008). Generation Y as hospitality employees: Framing a research agenda. Journal of Hospitality and Tourism Management, 15(1), 59-68.

22. Spiro, C. (2006). Generation Y in the Workplace. Defense AT\&1, 35(6), 16-19.

23. Terjesen, S., Vinnicombe, S., \& Freeman, C. (2007). Attracting Generation Y graduates. Organizational attributes, likelihood to apply and sex differences. Career Development international, 12, 504-522.

24. Treuren, G., \& Anderson, K. (2010). The employment expectations of different age cohorts: is Generation Y really that different?. Australian Journal of Career Development, 19(2), 49-61.

25. Zevenbergen, R. L. (2004). The emergence of the millennial: Intergenerational differences in contemporary workplace numeracy. 